Article

\title{
Feminist Theology, Plant Names, and Power
}

\author{
Shannon Craigo-Snell \\ Louisville Presbyterian Theological Seminary, Louisville, KY 40205, USA; scraigo-snell@lpts.edu
}

Received: 29 December 2018; Accepted: 8 March 2019; Published: 12 March 2019

Abstract: Decades ago, feminist theologians emphasized the importance of "naming" in achieving justice. They argued not having a name for something makes it more difficult to understand its influence on our lives. Naming elements of our lived reality (including patriarchy, specific barriers to women's flourishing, the patterns and values of relationships, and so forth) was seen as key to claiming the power to name ourselves and thereby claiming agency in a world of complex relations and interlocking injustices. Colonialist epistemologies and anthropologies that shape dominant culture in the U.S. prioritize universal over local knowledge, text-based propositions about objects rather than relational knowledge of subjects. While recent science draws attention to the interconnection and interdependence of human persons and our biological environment, there is little value given to local environmental knowledge of plant life. Feminist wisdom implies that this loss of naming for our own environment entails a loss of agency as well as a loss of understanding. Bringing feminist theology into conversation with science and indigenous ways of knowing, this paper argues that we cannot name ourselves if we do not have words for the plants with which we are interconnected on every level from basic sustenance to daily interaction to complex microbiology.

Keywords: plants; feminist theology; naming; relation; epistemology; self

\section{Introduction}

Walking the long way home

Walking ever so slow

Talking to be

Wholly in this world of wonder

Standing still

Waiting

Standing in the center

Of a long and winding

Dirt road

Leading uphill

To a small house

Surrounded by lilacs

Black-eyed susans

Roses and honeysuckle vines

A bench at the bottom

That bodies may rest

Before they climb

—bell hooks, Appalachian Elegy: Poetry and Place

"A rose by any other name would smell as sweet."

—Shakespeare, Romeo and Juliet 
In the following pages, I argue that naming plants is important for human identity and agency and further, that the practices of plant naming should be incorporated into local churches. The pattern of my argument begins with personal experience, draws from feminist theology, ecotheology, contemporary science, and indigenous ways of knowing, and concludes with an exhortation to churches to incorporate local plant identification into rituals and education programs as a way to rename congregation members into right relationship with creation. In keeping with the traditions of feminist theology, I begin with personal experience. My argument follows the feminist methodology of Letty Russell, a spiral that includes sharing experience, critical analysis, questioning tradition, and commitment to justice (Russell 1993, pp. 30-31). This method of engaging different resources enables me to analyze forms of knowledge that hinder intentional relating with nonhuman neighbors, analyze the harm of lost relation, and imagine small steps that could be taken towards a more just exercise of human agency within the interrelated whole of creation.

\section{Personal Experience}

I am a child of Appalachia. It was only after leaving West Virginia that I realized how deeply the geography and culture was imprinted on my mind and soul. How was I to know that pepperoni rolls are a local delicacy until I left and found New England tragically bereft of these delights? However, the real shock came when I moved to New Mexico. The flora of the high desert was foreign to me. Concretely, that meant I spent hours watering a tumbleweed in a misguided effort to keep my landlord's xeriscaped yard healthy. Spiritually, it meant I felt uprooted, misplaced, and profoundly disoriented.

Only in retrospect did I recognize the extent to which I had been educated in the names of the plants surrounding me in West Virginia. I remember the leader of my Brownie troop having all of us-girls of 6 or 7-pretend to be different types of trees. Straight and tall with arms upright for a poplar tree, arms out wide for an oak. A bit later in public elementary school, I was given an assignment to draw a map with every plant in our house or yard labeled. My mother kept multiple houseplants and we lived on a five-acre wooded property. (I did not do well on this assignment.) Church camp was another site of plant-name education, as our counselors (avid readers of the Foxfire books) taught us what was edible and what was not. My formal education in plant names culminated in high school, when passing Biology II required collecting and labeling 100 local wildflowers and being able to identify them on a test. My informal plant-name education was so subtle, it now seems that I always knew how to avoid poison ivy, that if I accidentally got into poison ivy I should immediately seek out tough-me-not stems to counteract the effects, that mayapples could be harvested and sold for real money, and that pokeberries—with their splattering purple juice-made perfect ammunition for battles among neighborhood kids. I secretly hoped to find a rare chestnut tree that had survived the blight and wasn't wormy, to go deep enough in the woods to see a plant without chlorophyll, and to witness the moment when the fern frond unfurls.

Once I recognized that not knowing the names of the plants in New Mexico was a loss to me, I set about learning them, which helped me feel both more at home and more myself. I have long since left New Mexico and my family has settled in Kentucky. Raising my children here, not too terribly far from where I grew up, I am aware that they are not being taught plant names in any of the formal settings that I was. None of my children are scouts, so perhaps that is a missed opportunity. The church camp movement of the 1970s-80s, where kids were sent off for a week or more to an outdoor-focused denominational church camp, has waned, and kids instead go on short, themed retreats with special speakers. They spend time in small groups and workshops rather than learning how to safely graze on the landscape. Assignments in public schools are not geared towards learning to name the plants in your home, yard, or county, but rather towards scoring well on standardized tests that are decidedly nonlocal, profit-generating products created somewhere in New Jersey. The erasure of plant names from children's education is not simply a recent trend of the past thirty years or a new 
reliance on standardized testing, but rather part of a longer philosophical and political trajectory in how knowledge is understood and valued.

\section{Knowing in an Age of Colonialism}

To understand why local plant knowledge is no longer emphasized in much of the U.S., and why this loss matters, it is helpful to rehearse a major epistemological shift that overlapped with Western colonialism. Several scholars have observed that the era of Western colonialism marked a significant shift in how knowledge was conceived and what types of knowledge were considered most reliable. The shift can be conceptualized in different ways. In my own teaching, I use René Descartes as a symbolic marker for the move to modern epistemology. His famous dictum, "I think, therefore I am," arose in the midst of his efforts to reconstruct his own knowledge of the world on a firm foundation through a rigorous program of doubt (Descartes [1637] 1999, p. 25). When faced with the apparent failures of academic and religious authorities and the exciting prospects of the scientific revolution, Descartes attempted to give an account of scientific knowledge on analogy with Euclidian geometry, honoring that which is always and everywhere true as most valuable. This value system still holds in many contexts: we expect scientific experiments to be replicable in different locations with consistent results. At the same time, Descartes' program identified quite particular objects of doubt as unreliable, including the senses, the emotions, and the wisdom of the community. In his efforts to construct a firm foundation of knowledge, Descartes also articulated a normative anthropology in which the human person is defined as an individual, autonomous, rational subject and agent. Regardless of Descartes' motives, this vision of humanity and knowledge has been part and parcel of oppressive systems. Native peoples, enslaved Africans, manual laborers, women-anyone who did not conform (by choice or coercion) to the image of normative humanity as an individual, disembodied, rational thinker-could be seen as less than human, and therefore rationally subject to inhumane treatment.

The epistemology and anthropology generalized as Cartesian paved the way for enormous scientific advancement, fueled and justified colonialist, racist, and sexist oppression, and, I will argue, pushed knowledge of plants away from local familiarity towards scientific inquiry for human use.

Diana Taylor describes the shift in epistemology during colonialism using an insightful typology. She asserts there are two different ways of creating, storing, and transmitting knowledge. One is the archive, wherein knowledge is written down or inscribed in some fashion. This would include such things as books, inscriptions, and legal codes. The other is the repertoire, wherein knowledge is performed. This would include such things as rituals, dances, and sports. Of course, the two often overlap and the categories are not pristine (Taylor 2003, pp. 18-22). However, noting their distinction allows Taylor to observe that part of what made the colonial project possible in the West was the separation of these two forms of knowledge and the elevation of the archive over the repertoire. This served the colonizers by legitimating their dismissal of the performative knowledge of indigenous peoples. Taylor notes that the archive is easier to control than the repertoire (Taylor 2003, p. 17). It is easier to control who learns to read and write, as well as who has access to pen, paper, and means of publication, than it is to control who dances or plays a game. By elevating the archive and controlling it, colonizers devalued the forms of knowledge available to colonized groups. In Taylor's analysis, the shifts in epistemology that took place during the colonial era were not incidental to the process of colonization, but rather vital to it. For my present argument, Taylor's work highlights how change in epistemology can serve political and economic interests and enable oppression and exploitation.

Like Taylor, performance theorist Dwight Conquergood diagnoses the emphasis on text-based knowledge that has dominated the Western academy as fundamentally oppressive. He writes:

The dominant way of knowing in the academy is that of empirical observation and critical analysis from a distanced perspective: "knowing that," and "knowing about." This is a view from above the object of inquiry: knowledge that is anchored in paradigm and secured in print. This propositional knowledge is shadowed by another way of knowing that is 
grounded in active, intimate, hands-on participation and personal connection: "knowing how" and "knowing who". (Conquergood 2004, p. 370)

Conquergood borrows the term "subjugated knowledges" from Michel Foucault to denote those ways of knowing that are "local, regional, vernacular." These are considered by many in the academy as "non-serious ways of knowing." "Subjugated knowledges have been erased because they are illegible; they exist, by and large, as active bodies of meaning, outside of books, eluding the forces of inscription that would make them legible, and thereby legitimate" (Conquergood 2004, p. 370). As noted above, epistemology and anthropology are intertwined. This text-based epistemology functions to devalue and even dehumanize groups of people. In the United States, people who are "undocumented" or "people without papers" are considered "illegal aliens" (Conquergood 2004, p. 371). There are similarly marked instances of text-based epistemologies dividing the haves and have-nots in other countries. Conquergood writes.

In Belize, for example, Garifuna people, an African-descended minority group, use the word gapencillitin, which means "people with pencil," to refer to middle- and upper-class members of the professional-managerial class, elites who approach life from an intellectual perspective. They use the word mapancillitin, literally "people without pencil," to refer to rural and working-class people, "real folks" who approach life from a practitioner's point of view. (Conquergood 2004, p. 372)

Such language exemplifies how text-based, nonlocal knowledge is privileged, and so too are the people who possess it. The shift towards this hierarchy of knowledge is made evident and magnified in the colonialism it fueled. While indigenous communities had unparalleled local knowledge, arriving colonizers claimed a kind of universal knowledge of surpassing value. This tightly relates to the social construction of race. European colonizers were unmoored from their specific localities and began to see themselves in one category (white) that was opposed and superior to the categories that they imposed on the wide array of peoples they encountered in Africa (black) or the Americas (brown) (Jennings 2010, pp. 16-64). The self-knowledge and self-naming of local communities was rejected by the colonizers who claimed a superior, larger perspective. Colonizers claimed an objective "view from above" that masked its own particularities (Conquergood 2004, p. 370). Central to the process of racialization was the separation (conceptual, theological, and physical) of identity and place (Jennings 2010, p. 30).

Although there are different ways to describe the process, various scholars agree that part of what empowered colonization was a shift in understanding and valuing knowledge, such that local, communal, performative, embodied ways of knowing were degraded, while purported objective, universal knowledge that claimed to be unreliant on community and embodiment was honored. Theologian Brian Bantum concisely states, "[i]n the modern world the realities of the slave ship and the encyclopedia converge" (Bantum 2010, p. 1).

It is important to note that Taylor and Conquergood do not point to the elevation of the archive and text-based knowledge as the root of the problem, nor do they see the way forward as a reversal in which repertoire and local, performative knowledges are deemed more valuable. Instead, both scholars see the separation of different ways of knowing (archive and repertoire, text-based and performative) as the root mistake. They advocate for ways of knowing that blur these lines and cross these boundaries.

Seen against this backdrop, the loss of local plant names in public education in the 21st century U.S. appears as an ongoing ripple of a wave that began long ago. The preference for nonlocal knowledge, abstracted from community and embodiment, endures in online education modules, standardized testing, and a thousand other pedagogical "innovations" or "reforms" that continue to elevate the kinds of knowledge most commonly held by white people with means. The work of scholars such as Taylor, Conquergood, and Bantum allows us to name the oppressive functions of this epistemology. 
This overview of colonialist epistemology and its concomitant anthropological hierarchies is a necessary background for understanding why knowledge of local plant names is diminished.

\section{Feminist Theology}

Feminist theology is helpful in conceptualizing just what we have lost in our lack of local plant name knowledge. In the Hebrew Bible, the first act of a human being is the act of naming. Genesis 3:20 states, "The man gave names to all cattle, and to the birds of the air, and to every animal in the field." Other biblical narratives, such as the story of Jacob wrestling the angel (Genesis 32: 24-29), indicate that to name someone or something is to have power in relation to that which has been named. What kind of power comes to be in naming varies in different interpretations and traditions. Many Christian communities have interpreted Adam's naming of the animals as divine sanction for human domination of creation. Alternatively, Jacques Derrida, after being seen naked by his small housecat, reads this Genesis narrative as differentiating both God and animals-in symmetrical or coincident fashion-from the human (Derrida 2008, p. 15-18). Within the wide variety of readings of biblical narratives, naming consistently recognizes relationship and therefore both performs and enables intentional interaction. Naming is associated with agency and power.

Feminist theology recognizes that women often have been restricted from the powerful place of naming and subjugated into the space of either being named or living in a reality that has been named by others. When women began infiltrating the ranks of academia, it was an opportunity for those who had previously been silenced to name their own experiences, perspectives, and reality. This was not understood in a merely additive way, in which women's naming would supplement or complement traditional (male) understandings. Rather, early feminist theorists and theologians saw the power of women's naming to potentially reshape human knowledge altogether. One key element was to name the structures that have prevented women from having the power to name.

In a volume appropriately titled, The Power of Naming, Elisabeth Schüssler Fiorenza uses the term "kyriarchy" to refer to "elite male-defined relationships of ruling" (Fiorenza 1996, p. xxi). It "is a socio-cultural, religious, and political system of elite male power, which does not just perpetrate the dehumanization of sexism, heterosexism, and gender stereotypes but also engenders other structures of women's oppression, such as racism, poverty, colonialism, and religious exclusivism" (Fiorenza 1996, p. xxi). Schüssler Fiorenza finds this term to be more attentive to interlocking systems of oppression than the term "patriarchy," which has been associated more strictly with gender-based oppression. In today's language, one could say that Schüssler Fiorenza's naming of oppressive structures is intersectional from the start. Her move to give systems of oppression a new, more precise, and encompassing name is not merely an exercise in academic ingenuity. Rather, it is part of the performance of feminist theology, which is, itself, a process of naming the world from the perspective of those who have not previously had the power to do so.

Because feminist theory, Schüssler Fiorenza asserts, "seeks not only to understand but also to change our knowledge of the world, it challenges the kyriarchal institutions which produce oppressive knowledges and which in turn are legitimated by it." (Fiorenza 1996, p. xix). Feminist theology operates similarly in a religious frame: "feminist liberationist theology names the death-dealing oppressive systems and powers of kyriarchy as structural sin and evil" (xxii). Christian theology, Christian institutions, and Christian communities have been sites of death-dealing knowledge production, teaching generations - through both archive and repertoire-hierarchical scales of worth and value whereby some humans matter more than others and all humans matter more than the animals, plants, and elements with which we cohabitate.

There are many reasons to argue that colonial epistemology does not fit well with Christianity. Some sticking points include the particularity of the relationship between ancient Israel and God, the centrality of Mary as the bearer of God, the incarnation of God in a poor, Jewish man, the empire-challenging life of Jesus narrated with acute sensitivity to the hungry, thirsty, sick, and vulnerable bodies in his community, and the sending of the Holy Spirit to enliven an ongoing 
communal body, to name a few. However, as a whole, Western Christianity has been intertwined with colonialism and the epistemology that emerged with it at every level (Jennings 2010 and Santmire 1985). The colonizer and the missionary both arrived with Bible in hand, declaring the superiority of a universally applicable, text-based, anthropocentric religion that was wielded for purposes of domination.

Much of the naming done by feminist theology in recent decades has critiqued and countered the epistemology that emerged in concert with colonialism. Individualistic, universalized ways of knowing that abstract from body and emotions are named as kyriarchal, that is, benefitting elite men and oppressing others. By naming "oppressive knowledges" as "sin and evil," feminist theology makes different knowledges possible. New naming — of experience, of the world, and of Divine-becomes possible. Although Taylor's categories are not often used, feminist and womanist theologians have resisted the separation of the archive and the repertoire, drawing on embodied and communal knowledge as it is transferred through performance. Hebrew Bible scholar Wilda Gafney likens her book, Womanist Midrash: A Reintroduction to the Women of the Torah and the Throne, to a supper table where all are invited to partake and to share. The metaphor of a communal supper allows Gafney to perform an inclusive form of scholarship that blurs the lines between different bodies of knowledge and ways of knowing (Gafney 2017, pp. 1-2). Lived experience-in precisely that overlap between individual and communal-has been honored as a resource for and object of theological reflection. Womanist theologian M. Shawn Copeland's text, Enfleshing Freedom: Body, Race, and Being, reflects explicitly on the embodied experiences of black women, including slavery and lynching, as a lens through which to understand Christian theology. Copeland writes, "reflection on these bodies, the body of Jesus of Nazareth and the bodies of black women, lays bare both the human capacity for inhumanity and the divine capacity for love" (Copeland 2010, p. 1).

Because colonialist epistemology is connected to a particular view of the human person (individual, autonomous, rational subject and agent), resistance to such epistemology goes hand in hand with reconceiving what it means to be human. There are multiple feminist and womanist ways of understanding humanity. Agreement on a singular definition of human personhood is neither sought nor found. However, amid the multiplicity, some themes emerge, including that the human person cannot be understood solely as a discrete individual.

\section{Relation}

This is true on many levels, including the ridiculously obvious. Each child is conceived in the relation between parents, emerges from another body, grows up in a particular community within a larger society within an interconnected global reality. Each child is born of a particular history of interaction between parents that takes place within the history of community and the history of a larger society within the history of the planet Earth. Spatially and temporally, we come to be in relation to other people. These relations are not just our origin stories, but also our ongoing realities. Who I am cannot be separated from the family I come from, the family I've built for myself, the friends who sustain me, the teachers who shape me, and the students I learn alongside. Such formative relationships have been undervalued in much of the Western philosophical tradition.

One of the early texts in feminist theology to delve into understanding the human person in relation is Catherine Keller's From a Broken Web: Separation, Sexism, and Self. Keller names the values that fund understandings of the human person focused on autonomy and individuality. She writes, "separation and sexism have functioned together as the most fundamental self-shaping assumptions of our time" (Keller 1986, p. 2). Tracing ideas through myth, poetry, psychology, feminist theory, and process theology, Keller sketches a different vision of the human person, a connective self that moves fluidly between previously polarized dyads of "(1) being one and being many; (2) being private or being public; (3) being body and being soul; (4) being here and being now" (225). The becoming of the self is located in a "whorl of internalized relations" (225). The integrity and distinguishability of such a self-becoming does not rely on separation and isolation, but rather on consistent and particular relating. 
Since Keller's pathfinding work, other feminist theologians have focused on different aspects of relating as central to what it means to be human. One recent work, The Goodness of Home: Human and Divine Love and the Making of the Self, by Natalia Marandiuc, brings together attachment theory, philosophy, and theology to articulate how attachment relations with significant others (such as parents and caregivers) provide a relational home in which the self comes to be. In Marandiuc's words, "The self is a composite of relations that constitute the self's home; the self is received as an inchoate gift, actualized through love that is received and called to live with the end of loving others as well as oneself" (Marandiuc 2018, p. 54). In conversation with Charles Taylor, Marandiuc describes the role of recognition within the development of the self in relation to others, a recognition that takes place within a larger horizon of meaning. She writes, "Recognition is a particular kind of dialogue that validates who, what, and how the other person is; hence, it presupposes a 'given' to be recognized yet, paradoxically, also contributes to the making of the 'given'"(Marandiuc 2018, p. 53). Misrecognition or malrecognition occurs in all systems of oppression, fueling and falsely legitimizing their functioning.

While Marandiuc's work emphasizes the importance of relationships between humans as vital to the self, other feminist theologians have envisioned relations constitutive to humanity in broader terms. Rosemary Radford Ruether was one of the first feminist theologians to address issues of ecology. She perceived the oppression of women and ecological destruction as connected manifestations of a cultural model of relationship as domination (Ruether 1983, pp. 72-85). Ruether identified the human person as a creature in the midst of an interdependent creation. For Ruether, reconceiving relation in nonhierarchical ways is vital to the flourishing of women and the Earth (Ruether 1983, pp. 85-92). Ruther identifies a way of thinking and living (one of domination) as fueling both sexism and ecological destruction. I have followed Ruether's logic in the analysis above, naming a particular type of epistemology and anthropology as vital to both colonialism and the loss of knowledge of local plants.

For several feminist theologians, including but not limited to Keller, Marandiuc, and Ruether, naming relations as constituent of human persons is important. Such naming contests harmful epistemologies and anthropological visions. It also opens up new fields of possibility and new ways of relating. Note that the particular ways that these theologians name relations neither claims nor asserts rightful power over nonhuman creation. Their naming of relations rebukes the interpretation of Adam naming the animals as a justification of anthropocentric sovereignty. While these authors describe the relations between humanity and the universe in unique and creative ways, they each identify an interdependence that disallows domination (Dalton and Simmons 2010).

Although their approaches have similarities, there are also significant differences in which relationships they identify and elaborate. Keller and Ruether, for example, speak of the interrelatedness of the entire cosmos. Marandiuc, in contrast, focuses on local, intimate relationships between a few significant others. The difference of scale is important and can be a space of real tension between those who emphasize a unifying relation of the cosmic whole (that then leads to new ways of relating locally) and those who highlight the intensely local (which then leads to new ways of understanding the universe) (Keller 1997, pp. 63-67).

\section{Science of Connection}

Modern science has changed quite a bit since Descartes attempted to account for the newly emerging scientific method some centuries ago. Contemporary research does not align with Decartes' understanding of the human person as an individual, autonomous subject and agent who thinks most clearly in abstraction from embodiment and community. Instead, relations and connections appear everywhere scientists think to look. We are, it turns out, actually stardust. The elements in our bodies come from stars and planets throughout the galaxy. The genetic picture of humanity is far more complicated than once thought. We are not only made from our parents' and grandparents' DNA, but perhaps also their histories. The theory of "epigenetic inheritance" posits that factors such as stress and diet, which affect our genes, can be passed on to our children. In particular, researchers 
have focused on how extreme experiences, such as war or famine, can switch on different genes in a way that becomes encoded in the genes of the next generation (Thomson 2015). It is not even just the genes of our ancestors that play around in our bodies, but also the genes of our children. Fetal cells and DNA continue within the bodies of the women who carried them, in ways that can change the women's health (Shute 2010).

Our bodies themselves are not discrete organisms, but rather collectives of organisms and biomes of life. Scientists now identify ecologies of microbes as interdependent on, and vital to, various parts of the human body. The "human microbiota"-all those forms of life that are part of our form of life-include bacteria, fungi, viruses, and "single-cell organisms known as archaea" (Davis 2018). The microbiome of any particular person is all the genes contained in their microbiota (Davis 2018). The microbes in our gut make digestion possible; some on our skin can fight cancer; and the relations between our microbes and different health conditions are just beginning to be understood (Davis 2018). David Kohn reports, "A growing group of researchers around the world are investigating how the microbiome ... regulates how people think and feel" (Kohn 2015).

In a widely read article in National Geographic, Ed Yong sensationalizes, "You could be sitting alone and still be completely outnumbered for your body is home to trillions upon trillions of tiny passengers-bacteria. Your body is made up of around ten trillion cells, but you harbor a hundred trillion bacteria" (Yong 2010). However, ongoing research reveals an intricate interdependence between humanity and bacteria that is far more complex than the term "passengers" implies (Shreiner et al. 2015). Our microbiomes are necessary for our existence and flourishing. We cannot be outnumbered if the bacteria in question are part of ourselves. Put differently: the conclusion that "we are more them than us" should make us rethink the division between "us" and "them."

The vision of a "separative self," as diagnosed by Keller, is no longer plausible; we are "connective" in a multitude of ways. Naming all of these relations is vital, for it creates agency. Our relations with our microbiomes have always been present; naming the organisms with which we are so intimately related allows us to be intentional in these relations. If we know that our digestive tracts are biomes of bacteria, then we have new options and insights regarding our choices in food and medicine. Similarly, naming intergenerational trauma empowers communities to address it directly and to engage in healing practices.

\section{Plants}

The connectivity I have been most intrigued by is that of human persons and plants. Again, there is a level that is obvious-we rely on plants for food, and therefore are profoundly dependent on plants. There are also levels that are not so obvious, especially to those of us conditioned by colonial epistemology and Cartesian anthropology. Ming Kuo, a professor at the University of Illinois Chicago-Urbana, has been studying the relationships between human beings and plants for decades. Originally skeptical of the idea that green spaces or plant life were particularly important for human beings, Kuo has been convinced by her research, and that of others, that proximity to plants and green spaces improves human social functioning, psychological functioning, and physical health (Vedantam and Kuo 2018). Kuo and her colleagues found that having "a bit of greenery" outside an apartment building improved the social functioning of the residents (including a higher sense of neighborliness and a lower incidence of aggressive behaviors) in comparison to that of neighbors inhabiting an identical building without plants outside. Studies have found adding green spaces to neighborhoods decreases crime rates within the community. Kuo states, "the consistent finding is more trees, less crime" (Vedantam and Kuo 2018).

There are also "dozens" of long-term health outcomes that are tied to "contact with nature." Being outdoors around plants connects to decreases in "obesity, hypertension, and diabetes." Carefully controlling for socioeconomic status and other variables, researchers found medications for anxiety and depression prescribed less often in greener neighborhoods of London. Spending three days in a 
forest boosts "natural killer cells" critical to immune response by $50 \%$. The effects linger, such that 30 days later these cells are still elevated by about 25\% (Vedantam and Kuo 2018).

My mother used to tell me that it made her happy to "dig in the dirt" tending flowers. Science can now back up her maternal wisdom. Microbes in soil are taken into the human body through our breath, if we are close enough, and act as natural antidepressants, elevating levels of serotonin and norepinephrine (Kennedy 2012). Who we are as humans is interrelated to plant life in more ways than we imagine. Every calorie we consume is dependent on the photosynthesis of our green companions; every breath reliant on the oxygen they produce. Our connection to the flora of the world is cosmological and complete. At the same time, it matters if the park is nearby, the tree visible, the dirt close enough to smell.

\section{The Leap}

If naming matters, and we exist and know in relation, and we are related to plants, then it matters if we know the names of the plants around us. Shakespeare was right-a rose by any other name smells as sweet. What the name is does not matter; that there is a name does. If I did not have any name for roses and I caught the sweet scent of their perfume, that smell would be fleeting, soon forgotten, unable to be cultivated in future experience or integrated into my own sense of self. Of course there are new experiences to be had which, one hopes, will involve unfamiliar flora and new fragrances. However, our recognition and wonder at the novel is, I argue, rooted in our intimacy with the known.

Consider, again, Marandiuc's use of attachment theory. She asserts that selves come to be in specific, intimate, local relationships that can create a particular home for the self's process of becoming. These local love relations are always set against a background of cultural meanings that condition them in various ways. Working within the traditions of Christianity, Marandiuc asserts that these local love relations are also set against the ultimate backdrop of God's love, which empowers the whole process. The particular attachment loves lead to broader love of neighbor, which again is empowered by divine love. In Marandiuc's view, the particular and universal cannot be set against one another, nor can either be ignored. Attempting broad neighbor love without first experiencing intimate attachment loves is not impossible, but it is profoundly difficult. Marandiuc relies heavily on attachment theory and psychology - discourses almost exclusively focused on humans-and her argument is not clearly transferable to nonhuman relations. It is, however, imaginatively so. Perhaps not only the humans closest to us but also the plants (and animals, and geography, and so forth) constitute the relational home in which we come to be. Without being able to name this relational home and the plants that form it, we cannot fully name ourselves and we experience a loss—or perhaps a distortion—of agency.

Earlier I stated that to tell another person who I am, I would have to narrate a whole set of relationships-I am Joanna's daughter and Elias' mother and Marilyn's friend. Perhaps I should also say that I sip the nectar of honeysuckle at every opportunity, cherish the scent of magnolia blossoms, and long for the season of Queen Anne's Lace. When I read the poem quoted at the beginning of this essay, the words transmit far more than can be accounted for in colonialist, Cartesian epistemology. I can smell lilacs, hear the buzzing of the bees around the black-eyed Susans, and feel the particular air of Appalachia. My calf muscles remember climbing hillsides of ancient mountains now worn low by time and sorrow and seasons and care. Hooks' words evoke complex emotions of belonging and absence, comfort and sadness. She, too, is a child of Appalachia, and her words conjure intensely local knowledge. This knowledge, carried on the names of plants, touches the whole person: intellect, emotion, body, and will.

Robin Wall Kimmerer, a member of the Citizen Potawatomi Nation and a botany professor, explicates the two different ways she was taught to know and name the plants around her. First is the way of her ancestors; second is her academic training. Her explication of these two allows a glimpse into a way of knowing that was explicitly attacked by the colonialists and the colonialist epistemology described above. It shows another way. In her youth, Kimmerer learned to understand the world as immersed in reciprocity_between humans, animals, plants, and the land (Kimmerer 2013, p. 9). 
She learned a "grammer of animacy" in which not only humans, but also animals, plants, rocks, rivers, and much else are not objects but subjects, living companions and family members (Kimmerer 2013, pp. 55-56). She repeats a central truth of this view: "[a]ll flourishing is mutual" (15). Not only did Kimmerer learn a world of reciprocity, animacy, and mutuality, she learned it with her whole self. She writes,

Native scholar Greg Cajete has written that in indigenous ways of knowing, we understand a thing only when we understand it with all four aspects of our being: mind, body, emotion, and spirit. I came to understand quite sharply when I began my training as a scientist that sciences privileges only one, possibly two, of these ways of knowing: mind and body. As a young person wanting to know everything about plants, I did not question this. But it is a whole human being who finds the beautiful path. (Kimmerer 2013, p. 47)

In sharp contrast with the indigenous way of knowing in which Kimmerer grew up, the Western academy is shaped by colonialist epistemology that prizes rationality in abstraction. In this way of seeing the world, plants and animals are objects towards which humans have no moral responsibility (57). Kimmerer demonstrates how colonial conquest-slowly unfolding through centuries of exploitation and displacement of indigenous communities-both enacted and required a view of nature as objects, commodities, and resources that are fundamentally interchangeable, like coins (17-18). The government's unrelenting demand that members of the Potawatomi Nation slice up the land on which they lived into individually owned plots of possession was not just a land grab. It was a pitched battle between two worldviews.

Like Taylor and Conquergood, Kimmerer does not respond to the denigration of one way of knowing (indigenous) by reversing the valuation and denigrating the other (scientific). Instead, she advocates for "cross-pollination" between the two (Kimmerer 2013, p. 47). Kimmerer draws on both ways of knowing in her teaching:

When I am in the woods with my students, teaching them the gifts of plants and how to call them by name, I try to be mindful of my language, to be bilingual between the lexicon of science and the grammar of animacy. Although they still have to learn scientific roles and Latin names, I hope I am also teaching them to know the world as a neighborhood of nonhuman residents. (Kimmerer 2013, p. 56)

This is vital to Kimmerer's understanding of right relations between humans and plants, as well as humans and the Earth more broadly. The "grammar of animacy" of her indigenous tradition shapes the language of the Potawatomi Nation, including the pronouns that are applied to plants. She writes:

Our toddlers speak of plants and animals as if they were people, extending to them self and intention and compassion - until we teach them not to. We quickly retrain them and make them forget. When we tell them that the tree is not a who, but an it, we make that maple an object; we put a barrier between us, absolving ourselves of moral responsibility and opening the door to exploitation. Saying it makes a living land into "natural resources." If a maple is an it, we can take up the chain saw. If a maple is a her we think twice. (Kimmerer 2013, p. 57)

The compelling possibility of new ways of relating with the world around us has led several contemporary scholars of religion to embrace animism, including Harvey Graham (see Animism: Respecting the Living World). Mark Wallace, in his text, When God Was a Bird: Christianity, Animism, and the Re-Enchantment of the World, argues that Christianity has animist origins. "Hidden in the bedrock of Christian theology is a grounding animist sensibility that construes all things-including the sentient and relational biomass that makes all life possible-as living enfleshments of divinity in the world" (Wallace 2019, p. 3). Christianity turned from its animist roots as it became increasingly a religion of the book, that is, of text. Wallace observes that among early Victorian scholars of religion, "the notion of animism was deployed as proxy for the benighted epistemologies of first peoples who 
envisioned the cosmos as an intersubjective communion of living beings" (p. 6). Of one such scholar, E.B. Tylor, Wallace writes, "Operating from a settler-colonialist mind-set, Tylor denigrated animism as the superstitious worldview of childlike tribes whose beliefs eventually gave way, in his thinking, to the march of reason and science in 'civilized' societies" (p. 7) One can almost imagine such colonialist authors saying of indigenous peoples, with dangerous paternalist inflection, “They don't know any better." The attitude towards animism among such scholars, as reported by Wallace, exemplifies a colonialist epistemology that values text-based, nonlocal knowledge and supports the relegation of all that is not human to the status of objects.

Wallace's intervention into Christian theology seeks to identify the animist past of Christianity in order to support an animist future, that is, to convince Christians to interpret their faith in a noncolonialist way and to relate to all creation as the dwelling-place of God. Ruether takes a different tack. She respects the truth of animism but sees the danger-perhaps especially within the human-centric traditions of Christianity - of anthropomorphic animism that would ultimately reinscribe humans as dominant in creation. Ruether chooses to use different language, more familiar to many Christians, declaring, "[w]e must respond to a 'thou-ness' in all beings ... [w]e respond not just as 'I to it' but as 'I to thou'" (Ruether 1983, p. 87). Martin Buber's description of "I and Thou" relations has been embraced by a great deal of Christian theology in the past decades. Here Ruether applies it not simply to relations between humans or between humans and the divine, but explicitly to relations between humans, animals, and plants. She chooses to expand a familiar concept rather than argue for an alternative interpretation of the origins of Christianity. This choice avoids, for good and ill, the larger history of how animism has been cast as an inferior epistemology. However, both Wallace and Ruether exhort Christians to see nonhuman neighbors as personal, spirit-filled, living beings with whom to relate. Both authors reject religious dominating and colonialist worldviews that misrecognize or malrecognize plants as objects rather than subjects, as commodities rather than communities.

This is not simply a misunderstanding of plants; it is a misunderstanding of who we are as human beings. Kimmerer describes the importance of recognition in regards to place, in a way that I believe is transferrable to plant life, as well. She recalls summer mornings as a child, when her father would start the day by pouring out coffee on the ground to honor the gods of the place in which they were camped for the night: "Here's to the gods of Tahawus," he said, when the family was camping on the mountain Tahawus in the Adirondacks. Kimmerer writes, "[w] hen we call a place by name it is transformed from wilderness to homeland" (Kimmerer 2013, p. 54). Recognition and naming-not only among humans-helps make a home for ourselves.

There is a deep generosity in Kimmerer's work that makes no sense from a colonialist epistemological viewpoint. She does not lay special claim to ownership or exclusive rights to wisdom based on her indigenous identity. Instead, Kimmerer identifies Skywoman, the original woman who fell from the Skyworld in the creation story of the Potawatomi as an "immigrant" (Kimmerer 2013, p. 8). "It was through her actions of reciprocity, the give and take with the land, that the original immigrant became indigenous" (9). Kimmerer holds out the possibility that those of us who are descendants of colonizers, as well as immigrants from around the globe, could become naturalized to the places we now inhabit. She is not saying we could become First Nations or Native Americans, but rather that we could learn to live in reciprocity with nonhuman neighbors whom we recognize as kin and with whom we seek mutual flourishing.

I was terribly disconcerted when I could not recognize and name the plants around me in New Mexico. It was a desert wilderness and I was an immigrant to its ecology. Learning the names-cottonwood, agave, sagebrush, chamisa, piñon-made the place feel more home-like and me feel less alienated.

\section{Church Planting}

The feminist theologians referenced throughout this paper proclaim-performatively and declaratively — that better understanding who we are-naming ourselves and our relations—can 
open new religious and spiritual possibilities. I concur. If my argument is persuasive, then those of us who locate ourselves within Christian traditions have work to do and roles to play. First, we should acknowledge our complicity in the sin and evil of structural oppression that has been fueled by colonialist epistemology and separatist anthropology. Sexism, racism, and ecological destruction are symptoms of the same sickness or, at the very least, comorbidities. Many Christian denominations and communities are already in the process of naming this complicity as unjust harm to others. A further confession is needed in recognizing that to the degree that we are beholden to colonialist epistemologies and anthropologies, we ourselves are disarticulated. As human persons we are split into pieces in our own understandings-body, mind, will, and emotion all disjointed. We are separated from the flora and fauna that — both outside and inside—-form the relational homes in which we come to be. Although the aspects of ourselves are already in relation, and we are not severed from the plant and animal life around us, our failure to recognize these relations and name those with whom we relate denies us the agency of intentional relating. Our inability to name those around us is an inability to name ourselves.

The next step is repentance-we should turn and walk the other way, towards right relationship with God and neighbor, human and plant, local habitats and the cosmos itself. Part of such repentance is to rename ourselves-not as rational individual agents, but as connective selves that are profoundly interrelated with all that is. This is not only ethically necessary, but theologically so, for the Cartesian self is an idol and an addict, hooked on fossil fuel and self-destruction (Vonnegut 2007, p. 42). We must take up the agency given to Adam in the book of Genesis, the opportunity to name the animals, and begin by renaming ourselves as creatures in a relational universe, distinguishable but inseparable from the ecology we are. To name these human animals well, we also need to name the plants-not in an encyclopedia written as an objective record of the view from nowhere, not in the notations of an avid collector, but in the greetings of interconnected life embraced by holy grace.

Local churches are, at our best and among other things, spaces where Christians teach our children and ourselves who we are. We page through the family album to tell the tales of Moses and Miriam, Abraham and Sarah and Hagar, Jacob and Leah and Rachel, Mary and Martha and all the rest. We sing songs about the animals on the ark, naming the elephants and camels as we point to pictures and play with wooden toys. There is both a gap and an opportunity here, to name the plants as well, both the many plants mentioned in the Bible and the ones growing right outside. If we did so, it could change the way we name ourselves. In baptism and regular liturgy, we name ourselves as beloved children of God. What that means could be richer, and our agency within it more connective, if we knew ourselves in relation to more than the humans and animals, if we knew ourselves in relation to plants.

Funding: This research received no external funding.

Conflicts of Interest: The author declares no conflict of interest.

\section{References}

Bantum, Brian. 2010. Redeeming Mulatto: A Theology of Race and Christian Hybridity. Waco: Baylor University Press, ISBN 978-1-60-258293-4.

Conquergood, Dwight. 2004. Performance studies: Interventions and radical research. In The Performance Studies Reader, 2nd ed. Edited by Henry Bial. New York: Routledge, pp. 369-80. ISBN 978-0-41-577275-4.

Copeland, M. Shawn. 2010. Enfleshing Freedom: Body, Race, and Being. Minneapolis: Fortress Press, ISBN 978-0-80-066274-5.

Dalton, Anne Marie, and Henry C. Simmons. 2010. Ecotheology and the Practice of Hope. Albany: State University of New York Press, ISBN 978-1-4384-3296-0.

Davis, Nicola. 2018. The Human Microbiome: Why Our Microbes Could Be Key to Our Health. The Guardian. March 26. Available online: https:/ / www.theguardian.com/news/2018/mar/26/the-human-microbiomewhy-our-microbes-could-be-key-to-our-health (accessed on 3 December 2018).

Derrida, Jacques. 2008. The Animal That Therefore I Am. Edited by Marie-Louise Mallet. Translated by David Wills. New York: Fordham University Press, ISBN 978-0-82-322791-4. 
Descartes, René. 1999. Discourse on Method and Related Writings. New York: Penguin Books, ISBN 0-14-044699-0. First published 1637.

Fiorenza, Elisabeth Schüssler. 1996. Introduction: Feminist Liberation Theology as Critical Sophialogy. In The Power of Naming: A Concilium Reader in Feminist Liberation Theology. Edited by Elisabeth Schüssler Fiorenza. Maryknoll: Orbis Books, pp. xiii-xxxix. ISBN 1-57075-094-7.

Gafney, Wilda C. 2017. Womanist Midrash: A Reintroduction to the Women of the Torah and the Throne. Louisville: Westminster John Knox, ISBN 978-0-664-23903-9.

Jennings, Willie James. 2010. The Christian Imagination: Theology and the Origins of Race. New Haven: Yale University Press, ISBN 978-0-30-015211-1.

Keller, Catherine. 1986. From a Broken Web: Separation, Sexism, and Self. Boston: Beacon Press, ISBN 0-8070-6743-1.

Keller, Catherine. 1997. Seeking and sucking: On relation and essence in feminist theology. In Horizons in Feminist Theology: Identity, Tradition, and Norms. Edited by Rebecca S. Chopp and Sheila Greeve Davaney. Minneapolis: Augsburg Fortress, pp. 54-78.

Kennedy, Pagan. 2012. How to Get High on Soil. The Atlantic. Available online: https:/ /www.theatlantic.com/ health/archive/2012/01/how-to-get-high-on-soil/251935/ (accessed on 7 November 2018).

Kimmerer, Robin Wall. 2013. Braiding Sweetgrass: Indigenous Wisdom, Scientific Knowledge, and the Teachings of Plants. Minneapolis: Milkweed Editions, ISBN 978-1-57-131356-0.

Kohn, David. 2015. When Gut Bacteria Change Brain Function. The Atlantic. Available online: https://www. theatlantic.com/health/archive/2015/06/gut-bacteria-on-the-brain/395918/ (accessed on 30 November 2018).

Marandiuc, Natalia. 2018. The Goodness of Home: Human and Divine Love and the Making of the Self. Oxford: Oxford University Press, ISBN 978-0-19-067450-2.

Ruether, Rosemary Radford. 1983. Sexism and God-Talk: Toward a Feminist Theology. Boston: Beacon Press, ISBN 0-8070-1205-X.

Russell, Letty. 1993. Church in the Round: Feminist Interpretation of the Church. Louisville: Westminster John Knox Press, ISBN 0-664-25070-X.

Santmire, H. Paul. 1985. The Travail of Nature: The Ambiguous Ecologial Promise of Christian Theology. Minneapolis: Fortress Press, ISBN 0-80060233309.

Shreiner, Andrew B., John Y. Kao, and Vincent B. Young. 2015. The Gut Microbiome in Health and Disease. US National Library of Medicine National Institutes of Health. Available online: https:/ /www.ncbi.nlm.nih. gov/pmc/articles/PMC4290017/ (accessed on 8 November 2018).

Shute, Nancy. 2010. Beyond Birth: A Child's Cells May Help or Harm the Mother Long after Delivery. Scientific American. Available online: https://www.scientificamerican.com/article/fetal-cells-microchimerism/ (accessed on 17 October 2018).

Taylor, Diana. 2003. The Archive and the Repertoire: Performing Cultural Memory in the Americas. Durham: Duke University Press, ISBN 978-0-8223-3123-0.

Thomson, Helen. 2015. Study of Holocaust Survivors Finds Trauma Passed on to Children's Genes. The Guardian. August 21. Available online: https:/ / www.theguardian.com/science/2015/aug/21/study-of-holocaustsurvivors-finds-trauma-passed-on-to-childrens-genes (accessed on 7 November 2018).

Vedantam, Shankar, and Ming Kuo. 2018. Our Better Nature: How the Great Outdoors Can Improve Your Life. Hidden Brain. NPR. Available online: https:/ / www.npr.org/templates/transcript/transcript.php?storyId= 646413667 (accessed on 13 November 2018).

Vonnegut, Kurt. 2007. A Man without a Country. New York: Random House, ISBN 978-0-8129-7736-3.

Wallace, Mark I. 2019. When God Was a Bird: Christianity, Animism, and the Re-Enchantment of the World. New York: Fordham University Press, ISBN 978-0-82-328131-2.

Yong, Ed. 2010. An Introduction to the Microbiome. National Geographic. Available online: https://www. nationalgeographic.com/science/phenomena/2010/08/08/an-introduction-to-the-microbiome/ (accessed on 8 November 2018).

(C) 2019 by the author. Licensee MDPI, Basel, Switzerland. This article is an open access article distributed under the terms and conditions of the Creative Commons Attribution (CC BY) license (http:/ / creativecommons.org/licenses/by/4.0/). 